\title{
Recent data on occurrence the sporophytes in populations of dioecious moss, Nyholmiella obtusifolia in North-Eastern Poland
}

\author{
Jakub Sawicki, Vítězslav Plášek, Monika Szczecińska
}

Recent data on occurrence the sporophytes in populations of dioecious moss, Nyholmiella obtusifolia in North-Eastern Poland. - Čas. Slez. Muz. Opava (A), 60: 7-10, 2011.

\begin{abstract}
Moss Nyholmiella obtusifolia is relatively common in Poland, but mostly sterile specimens are found in herbarium collections. Sporogenes were created very rare. During bryological explorations conducted in NE Poland in 2009 - 2011, sporophytes were found in four populations of $N$. obtusifolia, which account for approximately $7 \%$ of the surveyed populations.
\end{abstract}

Key words: Nyholmiella obtusifolia, sporogones, sporophytes, Poland

\section{Introduction}

The genus Nyholmiella Holmen \& Warncke contains two species, N. gymnostoma and $N$. obtusifolia, which have been described by Bridel as Orthotrichum gymnostomum and O. obtusifolium in the subgenus Orthophyllum.

The distinctness of species belonging to the subgenus Orthophyllum from other taxa of the genus Orthotrichum was noted by Delogne who was the first to place two species, O. gymnostomum and O. obtusifolium, into the subgenus Orthophyllum. Hagen (1908) went one step further, forming a separate genus for the above species, namely Stroemia Hag. They were distinguished by obtuse leaves with incurved or plane leaf margins and incrassate leaf cells with a stout central papilla on each side. Since Stroemia was an illegitimate name, it was later replaced by Nyholmiella Holmen \& Warncke (Damsholt et al. 1969). A later revision of the genus Orthotrichum resulted in the inclusion of O. gymnostomum and O. obtusifolium into Orthotrichum (Vitt 1973), as the above features were also observed in other representatives of this genus.

Nyholmiella obtusifolia and N. gymnostoma may be distinguished from each other on the basis of the peristome, which is double in the former and lacking in the latter. The gametophytes of the two species are easily separated by leaf margins and cell papillosity: $N$. gymnostoma has inrolled margins and two papillae per leaf cell surface, while $N$. obtusifolia has erect margins and unipapillose cell surfaces. During a bryological survey in Newfoundland (Canada) the hybrid between Nyholmiella obtusifolia and N. gymnostoma has been found (Hedderson 1986). The taxonomical characters are intermediate between the two taxa.

Phylogenetic studies of the genus Orthotrichum showed a clear distinctness between members of the subgenus Orthophyllum and the other Orthotrichum species, which supported the reactivation of the genus Nyholmiella (Goffinet et al. 2004, Sawicki et al. 2009, Sawicki et al. 2010). A molecular analysis with the use of selected classes of markers (nrDNA, cpDNA, ISJ and ISSR) resolved Nyholmiella as a sister group to monoecious Orthothrichum species with immersed stomata (Sawicki et al. 2009, Sawicki et al. 2010), surprisingly revealing a lower degree of genetic similarity to the dioecious Orthotrichum lyellii and monoecious Orthotrichum with superficial stomata.

Nyholmiella obtusifolia is widespread in the European continent (north to Svalbard), Greenland, the Caucasus, the Himalayas, Turkey, central and eastern Asia and North America. N. gymnostoma occurs in Europe (north to Fennoscandia), the Caucasus, Turkey, Afghanistan, Japan and North America. Both species can also be found in Poland (Ochyra et 
al. 2003). The populations of $N$. obtusifolia are relatively abundant, in both urbanized areas and natural forest ecosystems. $N$. gymnostoma has been seldom reported from Poland. Between ten and twenty localities of the species had been described by German botanists from the region of Warmia and Mazury (NE Poland), but despite a thorough exploration of the area the occurrence of $N$. gymnostoma could not be confirmed.

N. obtusifolia is relatively common in Poland, but mostly sterile specimens are found in herbarium collections. Sporogenes are seldom present. The mature capsule is oblongcylindrical, strongly 8 -ribbed to base and $1 / 2$ emergent. Stomata are superficial, located at or above the middle of the capsule. The peristome is double: 8 reflexed exostome teeth and 8 endostome segments. The calyptra is short-conic, naked, papillose. Spore size is from 20 to 25 $\mu \mathrm{m}$ (capsule development is shown in Figures 1-6).

On the territory where the species occur together, $N$. obtusifolia might be confused with Orthotrichum flowersii. However, O. flowersii has immersed stomata, reflexed to revolute leaf margins, and it is autoicous. In addition, $O$. flowersii does not have distal leaf cells with one papilla per cell, while $N$. obtusifolia does.

The taxonomic distinctness of N. gymnostoma and N. obtusifolia has been confirmed by molecular analyses. Nuclear ITS sequences, the chloroplast trnH-psbA region, and ISJ and ISSR markers revealed the existence of numerous species-specific substitutions, indels and bands (Plášek et al. 2009, Sawicki et al. 2009, Sawicki et al. 2010).

\section{Results and discussion}

During bryological explorations conducted in NE Poland in 2009 - 2011, sporophytes were found in four populations of $N$. obtusifolia, which account for approximately $7 \%$ of the surveyed populations. The locations of those populations are shown in Map 1. In the monitored populations, new sporophytes first appear in March and April, capsules mature and spores are dispersed in September and October. The studied populations were similar in terms of abundance, but they differed considerably with respect to the number of sporophytes. In 2009 - 2011, the highest number of sporophytes (23 to 34) was noted in the population located in Kortowo (a part of Olsztyn city). The number of sporophytes in the remaining populations ranged from 4 (Gietrzwałd village) to 11 (a population in the vicinity of Wyszków town).

The mechanisms determining sporophyte formation in the populations of dioecious mosses have not been investigated in detail to date. In the majority of dioecious moss species, sexual dimorphism is weakly pronounced, except in a few cases (Shaw \& Goffinet 2000). Among Orthotrichum species, differences in the size of males and females were observed in Orthotrichum lyellii (Vitt 1971). Male and female gametophytes may also differ in spore germination and clonal proliferation patterns (McLetchie 1992, Shaw \& Beer 1999). Due to the absence of differences in the structure of the vegetative organs, it is often impossible to determine whether both male and female plants are present in the population. The presence of representatives of one sex only is not sufficient for sporophyte development.

The success of sexual reproduction is also determined by weather conditions during the maturation of antheridia and archegonia. In mosses, fertilization occurs in the aquatic environment, and a distance between male and female plants is often a limiting factor. Sperm transport may be mediated by small invertebrates (Cronberg et al. 2006) whose presence may be another prerequisite for successful reproduction.

An analysis of the sex ratio in the populations of dioecious mosses is difficult due to low and periodically manifested sexual dimorphism. Sex-linked molecular markers are increasingly applied in bryological studies (McLetchie and Collins 2001, Fujisawa et al. 2001, Korpelainen et al. 2008). Such markers are currently being developed for Nyholmiella 
obtusifolia (Milewicz \& Sawicki 2011), in order to identify the factors affecting the sex ratio and sexual reproduction success in the populations of this species.

Acknowledgements: This study was made possible through financial support from Polish State Committee for Scientific Research (KBN grant N303 416237). Article has been also done in connection with project Institute of environmental technologies, reg. no. CZ.1.05/2.1.00/03.0100 supported by Research and Development for Innovations Operational Programme financed by Structural Founds of Europe Union and from the means of state budget of the Czech Republic.

\section{References}

Cronberg N., Natcheva R. \& Hedlund K. (2006): Microarthropods mediate sperm transfer in mosses.- Science, 313: 1225.

Damsholt K., Holmen K. \& Warncke E. (1969): A list of the bryophytes of Denmark.- Botanisk Tidsskrift, 65: $163-183$.

Fujisawa M., Hayashi K., Nishio T., Bando T., Okada S., Yamato K. T., Fukuzawa H. \& Ohyama K. (2001): Isolation of $\mathrm{X}$ and $\mathrm{Y}$ chromosome-specific DNA markers from a liverwort, Marchantia polymorpha, by Representational Difference Analysis.- Genetics, 159: 981-985.

Goffinet B., Shaw A.J., Cox C.J., Wickett N.J. \& Boles S. (2004): Phylogenetic inferences in the Orthotrichoideae (Orthotrichaceae: Bryophyta) based on variation in four loci from all genomes.- Monogr. Syst. Bot. Missouri Bot. Garden, 98: 270-289.

Hagen I. (1908): Forarbejder til en norsk lovmosflora. I. Orthotrichacea.- Det Kongelige Norske Videnskabers Selskabs Skrifter, 13: 1-100.

Hedderson T.A. (1986): A naturally occurring moss hybrid between Orthotrichum gymnostomum and $O$. obtusifolium from Newfoundland, Canada.- Bryologist, 89 (2): 165-167.

McLetchie D. N. (1992): Sex ratio from germination through maturity and its reproductive consequences in the liverwort Sphaerocarpos texanus.- Oecologia, 92: 273-278

McLetchie D. N. \& Collins A. L. (2001): Identification of DNA regions specific to the X and Y chromosomes in Sphaerocarpos texanus.- Bryologist, 104: 543-547.

Milewicz M. \& Sawicki J. (2011): Molecular identification of sex in dioecious moss Nyholmiella obtusifolia (Orthotrichaceae) on the basis of ISSR markers.- Čas. Slez. Muz. Opava (A), 60: 1-6.

Korpelainen H., Bisang I., Hedenäs L. \& Kolehmainen J. (2008): The first sex-specific molecular marker discovered in the moss Pseudocalliergon trifarium.- Journal of Heredity, 22: 1-7.

Ochyra R., Żarnowiec J. \& Bednarek-Ochyra H. (2003): Census catalogue of Polish mosses. Polish Academy of Sciences, W. Szafer Institute of Botany, Krakow, 372 pp.

Plášek V., Sawicki J., Trávníčková V. \& Pasečná M. (2009): Orthotrichum moravicum (Orthotrichaceae), a new moss species from the Czech Republic. Bryologist, 112(2):329-336.

Sawicki J., Plášek V. \& Szczecińska M. (2009): Preliminary Studies on the Phylogeny of the Genus Orthotrichum Inferred from Nuclear ITS Sequences.- Ann. Bot. Fenn., 46(6): 507-515.

- (2010): Molecular studies resolved Nyholmiella (Orthotrichaceae) as separated genus.- J. Syst. Evol., 48 (3): 183-194.

Shaw J. A. \& Goffinet B. (2000): Bryophyte Biology. Cambridge University Press.

Shaw A.J. \& Beer S.C. (1999): Life history variation in gametophyte populations of the moss Ceratodon purpureus (Ditrichaceae).- Am. J. Bot., 86: 512-521

Vitt D.H. (1971): The infrageneric evolution, phylogeny, and taxonomy of the genus Orthotrichum (Musci) in North America.- Nova Hedwigia, 21: 683-711.

- (1973): A revision of genus Orthotrichum in North America, north of Mexico.- Bryophytorum Bibliotheca, 1: $1-208$.

Authors' addresses: Jakub Sawicki \& Monika Szczecińska, Department of Botany and Nature Protection, University of Warmia and Mazury in Olsztyn, Plac Łódzki 1, 10-727 Olsztyn, Poland, e-mail: jakub.sawicki@uwm.edu.pl

Vítězslav Plášek, Dept. of Biology and Ecology, Faculty of Science, University of Ostrava, Chittussiho 10, CZ-710 00 Ostrava, Czech Republic,

e-mail: vitezslav.plasek@osu.cz 


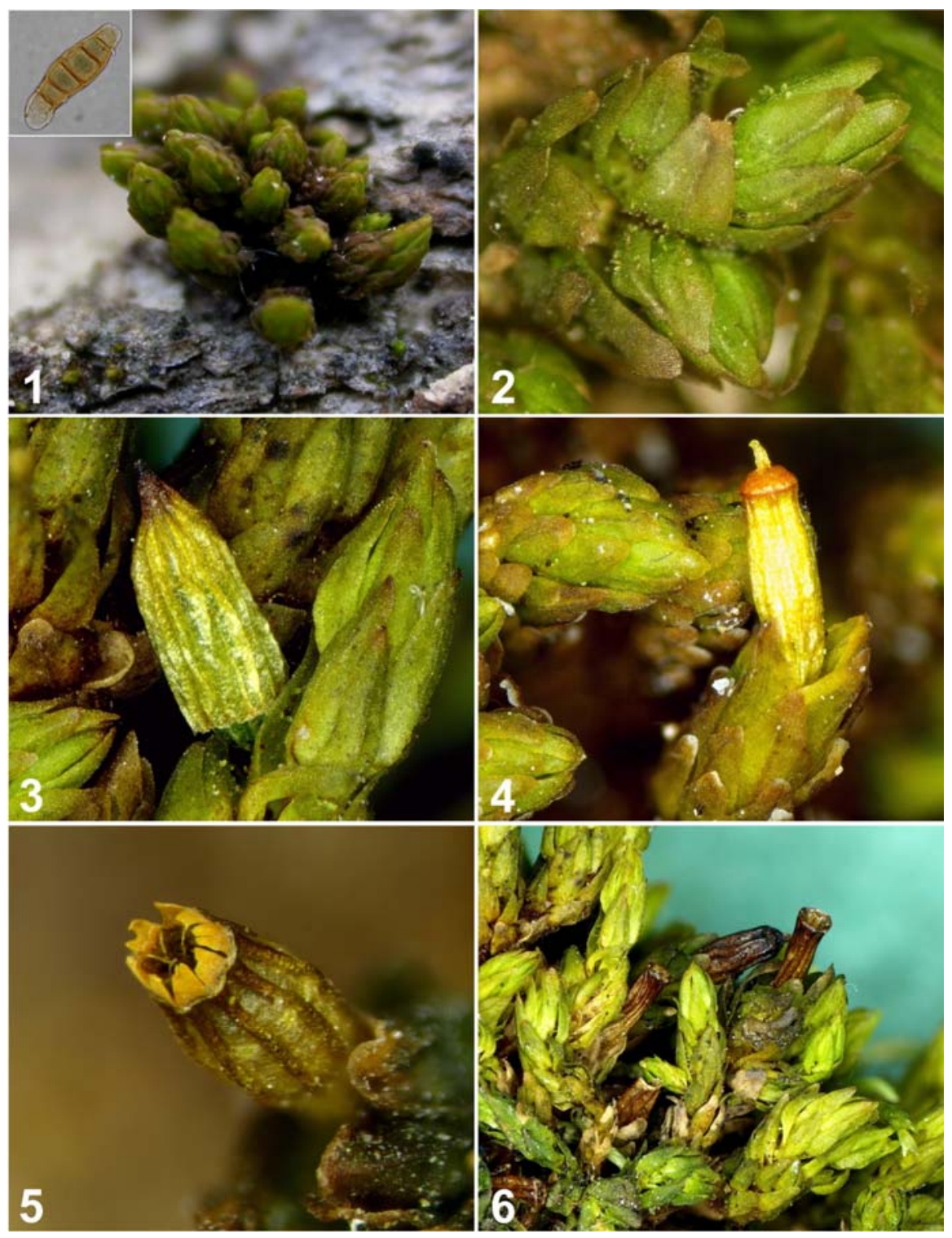

Figs 1-6: Photomicrographs of Nyholmiella obtusifolia ontogeny. 1. Sterile population with gemmae (in detail). 2. Sterile plants with gemmae presented on abaxial leaf surface. 3. Calyptra (naked). 4. Young capsule with the lid. 5. Peristome of mature capsule. 6. Old discharged capsules.

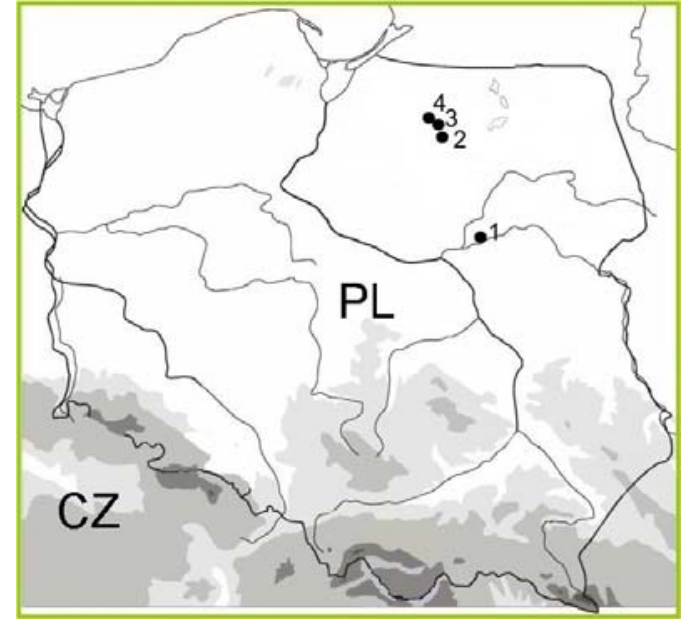

Map 1: Locality of the populations of Nyholmiella obtusifolia with sporophytes: 1 - Leszczedół near Wyszków, 2 - Baudy (22 km SE from Olsztyn), 3 - Olsztyn-Kortowo, 4 - Gietrzwald (17 km WN from Olsztyn). 